\title{
Eliciting donor preferences
}

\author{
Maren Elise Bachke, Frode Alfnes and Mette Wik \\ UMB School of Economics and Business \\ Norwegian University of Life Sciences
}

\begin{abstract}
:
Most charity organizations depend on contributions from the general public, but little research is conducted on donor preferences. Do donors have geographical, recipient, or thematic preferences? We designed a conjoint analysis experiment in which people rated development aid projects by donating money in dictator games. We find that people show strong age, gender, regional, and thematic preferences. Furthermore, we find significant differences between segments. The differences in donations are consistent with differences in donors attitudes toward development aid and their believes about differences in poverty and vulnerability of the recipients. The method here used for development projects can easily be adapted to elicit preferences for other kinds of projects that rely on gifts from private donors.
\end{abstract}

Keywords: altruism, charitable giving, conjoint analysis, dictator game, segmentation

\section{Corresponding author:}

Frode Alfnes

UMB School of Economics and Business

Norwegian University of Life Sciences

P.O. Box 5003, N-1432 Aas, Norway

Tel:+47 6496 5661/ Fax: +47 64965601

E-mail: frode.alfnes@umb.no

\section{Acknowledgements}

The authors gratefully acknowledge the financial support from the Norwegian Research Council, and help from the five Norwegian charity organizations that cooperated with us on this project: CARE (Norway), the Development Fund (Utviklingsfondet), Norwegian Church Aid (Kirkens Nødhjelp), Norwegian People's Aid (Norsk Folkehjelp), and SOS Children's Village (SOSBarnebyer). 


\title{
Eliciting donor preferences
}

\begin{abstract}
:
Most charity organizations depend on contributions from the general public, but little research is conducted on donor preferences. Do donors have geographical, recipient, or thematic preferences? We designed a conjoint analysis experiment in which people rated development aid projects by donating money in dictator games. We find that people show strong age, gender, regional, and thematic preferences. Furthermore, we find significant differences between segments. The differences in donations is consistent with differences in donors attitudes toward development aid and their believes about differences in poverty and vulnerability of the recipients. The method here used for development projects can easily be adapted to elicit preferences for other kinds of projects that rely on gifts from private donors.
\end{abstract}

Keywords: altruism, charitable giving, conjoint analysis, dictator game, segmentation

\section{Introduction}

Governments, companies, and private donors give large amounts of money in development aid, and the total net official development aid from the OECD countries was USD 148 billion in 2011 (OECD, 2012). A large share of these donations goes to development projects run by nongovernmental organizations (NGOs) such as Save the Children and the Red Cross. The level of private funding varies significantly among NGOs working with development aid. Taking Norway as an example, some Norwegian NGOs collect more than $90 \%$ of their income from private donors, while others receive as much as $80 \%$ from the Norwegian government (Bolle, 
2010). The percentage of Norwegian households giving to development aid organizations was 43 percent in 2009 (Wollebæk \& Sivesind, 2010). Hence, the organizations have ample experiences in collecting money from the public, but they have little empirical research on private donor preferences on which to build their campaigns. This despite the very large sums collected by these charity organizations.

Development projects differ from ordinary products in that the donors do not get anything tangible in return for their money, however they might get what economist call warm glow (Andreoni 1990) - a positive felling from conducting an altruistic action. Donors are therefore likely to have preferences regarding the use, and not at least the consequences of their donations. Most of the research on donor preferences is based on surveys, and as discussed by e.g., Burt and Popple (1998) and Lee and Woodliffe (2010), the data validity of surveys on giving to charities are likely distorted by donors over-reporting according to what is socially desirable. One way of reducing the social desirability bias (Fisher, 1993) is to impose real economic incentives in the method used to elicit preferences (Norwood and Lusk, 2011). In this paper, we present a conjoint analysis experiment with real money donations to provide insights into the kind of projects private donors want to support.

Conjoint analysis is a widely applied marketing research method used to investigate consumer preferences for a large number of product attributes and attribute combinations (Wittink, Vriens, \& Burhenne, 1994). By asking participants to evaluate a series of products that differ in attributes, one can use statistical methods to analyze how the presence or absence of various attributes influence people's choices. This type of analysis can provide implicit valuations, which can be used to design new products or services, or in guiding marketing campaigns. 
The conjoint analysis methodology can be divided into rating-based conjoint methods (see, for example, Otter, Tuchler \& Fruhwirth-Schnatter, 2004) and choice-based conjoint methods (see, for example, Vermeulen, Goos, \& Vandebrosk, 2008). In rating-based conjoint studies the respondents rate their liking for a series of product profiles on a scale such as 1 to 20 , while in choice-based conjoint studies (often referred to as choice experiments) respondents choose between product profiles. In both cases, the product profiles include a series of product attributes, and by investigating the effects of changes in the attributes on the product rating or choice frequencies one can estimate the underlying preference function for products in terms of their attributes (see, for example, Green \& Srinivasan, 1990; Green, Krieger, \& Wind, 2001; Rao, 2008).

Our study use a rating based conjoint, but the design departs from other rating-based conjoint studies in that it uses a well-tested game from behavioral economics in the rating of the development aid projects. Whereas most rating-based conjoint studies ask the respondents to rate their liking for products on a scale (Otter, Tuchler, \& Fruhwirth-Schnatter, 2004), our respondents show their liking for development aid projects by the amount of real money they donate to the project in an experiment using the dictator game from behavioral economics. Hence, the rating has real economic consequences for the participants.

The dictator game is a common way to measure altruistic preferences in behavioral economics. In dictator games people are asked to divide a pile of money between themselves and a second party (see, for example, Hoffman, McCabe, \& Smith, 1996; Cappelen et al., 2007). People can keep all the endowed money for themselves or give some or all of it to the second party. Contrary to the predictions of traditional economic theory, people seldom keep all the 
money for themselves, and the amounts they give away depend on who the receiver is (see, for example, Andreoni et al., 2007, or the recent meta analysis by Engel 2011).

Most dictator game studies involve only one type of recipient, an anonymous person that usually has the same background as the one dividing the money. In a few studies, the participants are informed about one or two characteristics of the recipients like the gender (e.g., Dufwenberg, and Muren 2006) or the name of the organization (e.g., DellaVigna et al., 2012). To our knowledge, no previous study using dictator games has tried to elicit donor preferences for a large number of recipient characteristics. Our design, combining conjoint analysis and dictator games allows us to elicit and compare donor preferences for a large number of recipient characteristics, and therefore differ from other dictator game designs in the scope of different recipients included.

A dictator game used for rating charity projects has direct economic consequences for the participants. We are not aware of any previous studies using real economic incentives in a ratingbased conjoint study, but several studies use real economic incentives in choice-based conjoint experiments. Three of these studies compare the ability of conjoint analysis experiments with and without real economic incentives to predict market shares of goods (Ding, Grewal, \& Liechty, 2005; Chang, Lusk, \& Norwood, 2009; Dong, Ding, \& Huber, 2010). All three studies conclude that research using real economic incentives outperformed the hypothetical studies. For a comprehensive discussion of the pros and cons of real economic incentives in experiments, see Barsley et al. (2010: 244-285).

We used a Norwegian sample to illustrate how conjoint analysis and dictator games can be combined to elicit donor preferences for a large number of development aid project characteristics in an experiment with real economic incentives. Combining the conjoint analysis 
with a dictator game, we are able to shed some light on donor preferences for various development aid project characteristics such as the age and gender of the recipient group, recipient region, and project type. To illustrate the possibilities for segmentation, we also include gender segments in the results.

The remainder of this paper proceeds as follows. First, we provide a short overview of earlier literature on charitable giving. Second, we describe the sample, questionnaire, and experiment. Third, we present a theoretical and empirical model to analyze the experiment data. Fourth, we present results from the questionnaire. Fifth, we present results from the conjoint analysis dictator game. Sixth, we conclude with a discussion of the results in relation to earlier literature on charitable giving and relevance to the charity industry.

\section{Previous research on charitable giving}

\subsection{Motivation, fundraising strategies, and cost of giving}

A general finding from dictator games is that the majority give money when they are asked to divide a sum of money between themselves and another party. This has induced numerous researchers to investigate the motivation for such behavior (see Andreoni, 2006, and Engel, 2011 for an overview). The most common explanations for giving are altruism (Andreoni, 1990) and social pressure (Akerlof \& Kranton, 2000). For some types of fundraising, such as door-to-door, both altruism and social pressure are likely to play an important role (DellaVigna et al., 2012).

Andreoni (2007) divide the actors in the charitable marketplace into three types: the

donors of money, the charity organizations that receive it, and governments. Charitable organizations represent the demand side of the market. A few studies have investigated how 
fundraising strategies such as revealing the identities of donors, offering "seed grants," or holding lotteries can affect donations (Rege \& Telle, 2004; List \& Lucking-Reiley, 2002; Landry et al., 2006). However, to our knowledge, no studies have focused on the type of projects charity organizations should promote in order to induce private donors to give.

Governments are involved in charities in a number of ways, including giving money to charity organizations and allowing individual tax payers to deduct charitable donations from their taxable incomes. A few studies have looked at crowding-out effects from governmental giving to charities (see, for example, Andreoni \& Payne, 2007), and others have measured the responsiveness of giving to cost (see, for example, Andreoni \& Vesterlund, 2001). We do not discuss the role of the government in this paper.

\subsection{The effect of knowledge about recipient characteristics}

The standard procedure in experimental economics is to maintain the anonymity of laboratory participants. However, several studies have been conducted to observe how donations in dictator games are affected by information about the recipient, a continuation of the idea of the “identifiable victim" first presented by Schelling in 1968. These studies found clear evidence that the size of donations is affected by the identity of the recipient. The focus in the literature has mainly been on varying degrees of anonymity and social distance between people (see, for example, Bohnet \& Frey, 1999a, 1999b; Charness \& Gneezy, 2008). In this paper, we focus on the literature on donations to organizations.

According to the meta analysis by Engel (2011), people share an average of about $28.35 \%$ of the pie in dictator games. Yet, these studies show large variation in donations. Working for money, anonymity, and the possibility of taking money from the respondents all 
significantly reduce the amounts given (Cherry et al. 2002; List 2007). The recipients being charity organizations instead of fellow students or similar gives significantly higher donations. Eckel \& Grossman (1996) were the first to investigate the latter. They compared dictator games where the recipients were either anonymous individuals or the American Red Cross, and found that their participants gave three times more when the American Red Cross was the recipient.

Based on the results of their manipulation (the recipient being a student or the Red Cross) Eckel \& Grossman (1996) concluded that subjects are rational in the way in which they incorporate fairness into their decisions. Other studies have found that subjects also differentiate between charity organizations and between charity projects. DellaVigna et al. (2012) found that people are more likely to give money to a more popular charity than to a less popular one in a door-to-door fundraiser. Benz \& Meier (2008) reported that students at the University of Zurich gave more to university charities than to other charities. Carpenter, Connolly, \& Myers (2008) found that their participants donated more when the charity was of their own choice. Fong \& Luttmer (2009) conducted a dictator game to investigate how characteristics of charity beneficiaries affected donations after Hurricane Katrina. They found that respondents significantly increased their giving when beneficiaries of the charities were perceived to be living in a more economically disadvantaged city.

Donors also have preferences for how the money is used. Breman et al. (2009) found that donors gave more in situations where they could decide exactly how the money would be spent than if they could only donate money to a general cause. In addition, studies of donations to environmental organizations show that subjects care about how their money is spent. Carlsson \& Martinsson (2001) used a choice-based conjoint experiment with real economic consequences to evaluate preferences for donations to environmental projects run by the World Wildlife Fund. 
They found that Swedes prefered environmental projects conducted in the nearby Baltic Sea or in the rainforest over those conducted in the Mediterranean. Johansson-Stenman \& Svedsäter (2008), using a similar design, found that individual donors were more willing to give to a campaign supporting the African Elephant than one supporting the Green Sea Turtle.

Altogether, these papers provide strong evidence that people have preferences for how the money they donate is used, and vary their donations based on characteristics of the recipients. However, none of the above papers differentiates between more than five different recipients. Nor do they look at characteristics of development aid projects such as the age and gender of the recipients, the regions the money will go to, or the type of project the money will be use for.

\subsection{Donor segments}

Several researchers have investigated gender effects in dictator games and the results are mixed. Eckel \& Grossman (1998) found that women give more than men in these games, while Bolton \& Katok (1995) found no significant difference. Andreoni \& Vesterlund (2001) compared gender behavior in dictator games by varying the monetary value of the tokens being divided among players. They found that women gave more overall and were more likely to divide tokens evenly despite the different monetary values, while men became less generous as the value of their tokens increased relative to the value of the responders' tokens. Carpenter, Connolly, \& Myers (2008) found that the age of the donor played an important role, and older people gave more than younger people. Engel's (2011) meta analysis confirm that gender and age significantly affect the amount given in dictator games. Supphellen \& Nelson (2001) developed a typology of private philanthropic decision-making based on cognitive and behavioral questions in a survey, and found that segments behave differently with respect to donations to charities. 
Altogether, these papers provide strong evidence that contributions to charities vary among donor segments.

\subsection{Donations to charities}

Micklewright \& Schnepf (2007) investigated donors giving financial contributions to overseas development causes in the UK. They found that a larger proportion of women donated to overseas charities than men, but that the mean value of donations did not differ significantly between men and women. This contrasts with giving to domestic causes, where men on average donate more than women. Another paper by Atkinson et al. (2008) investigated changes in behavior of individual donors in the UK during 25 years. They found that private donations to development charities increased at an annual rate of $7.5 \%$ over the period, compared with an average of $2.5 \%$ growth in GDP. The growth was not steady, however, but surged at times such as during and after the African Famine in 1985-1987.

\subsection{External validity of giving in the laboratory}

Most studies of people's willingness to give are conducted in laboratories, however many factors vary between experimental settings and the field (Levitt \& List, 2007). Most notably, the context of the giving differs with respect to where the money is coming from (earned in the labor market vs. endowed in the experiment) and the awareness of being observed, which might increase tendencies towards socially desirable behavior. Does this mean that people behave differently in the laboratory than in the real world? Andreoni \& Miller (2002) found that most of the participants in their dictator games were rational altruists, meaning that they had consistent and predictable preferences for altruistic giving. This indicates that altruism seen in dictator games 
does not contradict economic theory. Laury \& Taylor (2008) found that laboratory behavior could predict contributions to naturally occurring public goods, but not on an individual level. Benz \& Meier (2008) found correlations between laboratory and field donations of around 0.3, and that more people donated money in the laboratory than in the field. Levitt \& List (2007) argue that since the properties of the situation are potentially quite different across the laboratory and field domains, one should not expect the quantitative insights to be congruent. Rather, it is comparative statics that are most reliably transferred across domains. As a consequence of the difference between laboratory and field, the focus of most laboratory studies is on the effects of various treatments and differences between segments, and little is inferred from the absolute amount given. For a balanced discussion of external validity issues related to experiments, see Falk and Heckman (2009).

Survey data on donations have also been found to have validity problems. Burt and Popple (1998) studied participants’ memory for charitable acts, including the amounts they donated to charity and the frequency of such donations. They find that recall of both the amount donated and frequency of donations produced significant overestimations. They therefore question the validity of survey data on donation size and frequency.

\section{The experiment}

\subsection{The sample}

The experiments were conducted at a Norwegian university in October and November 2009. Two hundred and forty students participated in one of 11 sessions lasting approximately one 
hour. In this paper we use data from the 90 participants that took part in the sessions using project profiles with three attributes. ${ }^{1}$

The students were recruited at the university, either through visits during class hours, posters on campus billboards, or flyers in the main cafeteria. In the recruitment process, the students were asked to take part in an experiment in human decision-making. They were not informed about the purpose of the experiment, nor about how much money they would receive. The students who wanted to participate in the experiment could choose a suitable time and date from a list of alternatives. Groups of 9-27 students met in a classroom with ample space.

Table 1 presents some descriptive statistics for the participants. Their ages ranged from 19 to 46 years, with an average of 22 years. Seventy percent of the participants were women. On average they had studied almost three years at university level, 50\% were bachelor's degree students and $47 \%$ were master's degree students. Thirty-three percent of the participants were students in economics, $15 \%$ studied other social sciences, and the rest were science students.

\subsection{The experimental session}

The experimental sessions included a survey, a dictator game, and a stated choice experiment. In this paper we mainly consider the dictator game. When the participants arrived they were given an envelope with NOK $250,{ }^{2}$ and asked to take a place in a large classroom. We started the

\footnotetext{
${ }^{1}$ The remaining sessions used only two attributes and are analyzed in a second paper looking at the effect of the amount of information.

${ }^{2}$ According to www.oanda.com, NOK 1 = US\$ 0.17 and NOK $250=$ US\$ 43.02 on October 1, 2009.
} 
session by giving the participants an introduction to the experiment, told them about the financing from The Norwegian Research Council, and informed them about the five charity organizations $^{3}$ that would receive the money they donated during the experiment.

After the introductory talk, the participants filled out a questionnaire on their knowledge about, and attitudes toward, development aid. Second, we conducted a dictator game, in which each participant had to decide how to split the NOK 250 between himself or herself and a charity project. This was repeated for 15 charity projects. We had four versions of the form, and across all participants 60 charity projects were included. Third, one of the participants drew a number between 1 and 15, and all participants were asked to mark the corresponding project on their form. They were informed that this project would receive the money they had decided to donate. Fourth, the participants completed the stated choice experiment. Fifth, the participants answered the second part of the survey, which included questions about political preferences, behavior, and demographics. Finally, the participants entered a separate room one by one and put their completed questionnaires and the money they wanted to donate to the selected charity project into a blank envelope, which was then placed in a box. We used this double-blind procedure to secure anonymity and thereby minimize the effect of social pressure and any potential perceived reciprocity effects.

3 These organizations were CARE (Norway), the Development Fund (Utviklingsfondet), Norwegian Church Aid (Kirkens Nødhjelp), Norwegian People’s Aid (Norsk Folkehjelp), and SOS Children’s Village (SOS-Barnebyer). 


\subsection{The dictator game}

The dictator game was constructed as a conjoint analysis experiment with real economic consequences. The experiment included 15 project profiles, each described by three factors: recipient group (children, girls, boys, women, and men), recipient region (Sub-Saharan Africa, South and South-East Asia, Middle-East, Latin America, and Eastern Europe), and project type (education, health, peace and reconciliation, agriculture, and business development). However, unlike ordinary conjoint analysis studies in which participants evaluate their liking for the profiles on a scale, our participants took part in a dictator game and were asked to donate anything from NOK 0 to 250 of the NOK 250 they had received at the start of the experiment. See Table 2 for an example of three of the 60 project descriptions used in the dictator game.

When we explained the dictator game, we illustrated the regions on a world map and provided examples of projects in each of the project types. For example, an educational project could include building schools, buying books, or educating teachers. We also carefully explained the drawing of one binding charity project and the anonymity secured by the final step of the experimental procedure. Anonymity is an important part in the design, to make the experiment as authentic as possible and to reduce the effect of social pressure from scrutiny.

After creating the project profiles we asked the five charity organizations to suggest matching development projects. We explained to the participants that behind the different project profiles there were real development aid projects run by the five charity organizations. However, we did not tell them which organization was responsible for each project. We informed them that the money they gave to the drawn project would be donated to a similar project run by one of the charity organizations we cooperated with. Some of the profiles did not have matching projects. These profiles were therefore excluded from the draw. 


\subsection{Fractional factorial design}

With three attributes (recipient group, recipient region, and project type) which have five levels each, there are 125 possible combinations of the attribute levels, i.e., the full factorial has 125 project profiles. This is too many project profiles for each of the participants to evaluate, so we decided to go for fractional factorial design, i.e., a subset of the full factorial. We decided that each participant could evaluate 15 profiles spread over two pages. To get a good spread in attribute combinations we decided to create four versions with 15 profiles each, in total 60 project profiles.

To secure identification of the main-effects we used a SAS macro (\%mktex) to generate the fractional factorial design with minimal correlation between the attributes. We restricted the design so that children were not combined with the agriculture and business development project types. SAS reported a D-efficiency of 93.91 (out of 100) for the design, indicating that the attributes exhibit very little correlation across the project profiles. A D-efficiency score of 100 indicate no correlation between the attributes, but with our restriction on children that was not possible. The 60 project profiles were divided into the four groups of 15 profiles using the SAS procedure proc optex. This secured that even within the four groups of 15 profiles, the correlation in attributes should be minimal and that the attribute levels should be spread equal over the four groups of profiles. Finally, to mitigate any ordering effects the order of the project profiles was randomly arranged within each of the four groups. For a description of the SAS macro and procedure, see Kuhfeld (2009).

\section{Theoretical and empirical model}




\subsection{Theoretical model}

In a paper comparing laboratory experiments on social behavior with real-world behavior, Levitt \& List (2007) formulate a utility maximization model in which utility is additively separable in the moral $(M)$ and wealth $(W)$ arguments. The utility function for individual $i$ is:

$U_{i}(a, v, n, s)=M_{i}(a, v, n, s)+W_{i}(a, v)$.

The wealth effect $\left(W_{i}\right)$ is a function of the choice regarding a single action $a$ and the stakes or monetary value of the game, denoted by $v$. In situations without a moral component $\left(M_{i}\right)$, the model becomes a standard wealth maximization problem. However, in many cases the wealth maximizing action has a moral cost or benefit associated with it. The moral cost increases as the negative impact of an action on others increases. In this model this externality is seen as an increasing function of stakes in the game $(v)$. Another factor that influences the moral cost is the set of social norms or legal rules in the society $(n)$. The stronger the norms or rules against a certain action, the higher is the value of $n$. Finally, the moral costs depend on to what degree and how an individual's actions are scrutinized, denoted by $s$. Higher levels of $s$ are associated with greater moral costs. The model envisions a trade-off between morality and wealth. The stronger the social norm against a wealth maximizing choice, or the more the action is scrutinized if the action has a social cost, the less probable it is that the agent will make this choice.

In our study, the moral cost of keeping money for oneself depends on the perceived impact of the projects on the recipients' lives and the norms or attitudes associated with development aid. Based on Levitt and List's model we expect the following: (1) donations 
should be highest for project benefiting those perceived most vulnerable and poor and the to those project types perceived most effective in improving the lives of the recipients (perceived impact); (2) donations should be highest among groups most positive to increasing Norwegian official development aid (attitudes and norms); and (3) donations should be higher than what one could expect outside the lab (scrutiny). The third measure, scrutiny was reduced as far as possible using a double-blind design, and was held constant over all participants. Therefore, we do not report any further on scrutiny.

\subsection{Empirical model}

Each of the 90 participants ( $i=1$ to 90 ) evaluated 15 project profiles ( $j=1$ to 15 ) by donating money. Each project profile described a charity project using three five-level categorical attributes: recipient group $\left(\mathrm{x}_{1 i j}\right)$, recipient region $\left(\mathrm{x}_{2 i j}\right)$, and project type $\left(\mathrm{x}_{3 i j}\right)$. To assess the effects of the various project attributes on the amount donated, we set up an additive main effect model. Because the project attributes $\left(\mathrm{x}_{1 i j}, \mathrm{x}_{2 i j}, \mathrm{x}_{3 i j}\right)$ are five-level categorical variables, we transform them into a series of dummy variables, yielding the following model:

$Y_{i j}=\beta X_{i j}^{\prime}+v_{i}+\varepsilon_{i j}$

where $\mathrm{Y}_{i j}$ is the donation made by participant $i$ for the $j$-th project offered to him, $\mathrm{X}_{i j}$ is a vector including the attributes of the $j$-th project offered to participant $\mathrm{i}, v_{i}$ is the individual-specific random term, and $\varepsilon_{i j}$ is the residual. Our dependent variable is censored because there may have been participants that wanted to give less than NOK 0 and more than NOK 250, two options that were not possible. Thus, the dependent variable was censored with a lower limit of 0 and an 
upper limit of 250. We therefore estimated the model using a panel Tobit estimator, ${ }^{4}$ assuming a normal distribution of the residual, and as a random effects model. Finally, we used the panel structure in the estimations because we use panel data with 15 observations per participant. It is worth noting that the main effect model allows us to estimate expected donations for 125 $(5 * 5 * 5)$ different attribute combinations, which is significantly more than the number of recipient types included in earlier dictator games.

In addition to exploring the effect of attributes on willingness to give for the whole sample, we also illustrate how the method can be used to investigate segmentation variables. We split the sample and estimated equation (1) for women and men separately.

\section{Results from the survey}

\subsection{Participants' impressions of the levels of poverty and vulnerability in the recipient groups} and regions

The participants were asked to assess the vulnerability of the recipient groups from "extremely vulnerable" (value 1) to "not vulnerable at all” (value 7). They were also asked to make similar assessments from "a high degree of poverty" to "very little poverty" for each of the recipient regions.

\footnotetext{
${ }^{4}$ The model was also estimated using an interval regression, however, these results were not significantly different from the results we present here, thus for presentational reasons we have only presented the Tobit results.
} 
Table 3 shows how the participants evaluated vulnerability and poverty in the different groups. On average, they believed that girls were the most vulnerable, followed by women, boys, and men. They also deemed Sub-Saharan Africa to be the most impoverished region, while Eastern Europe was the region with the least poverty. There were no significant differences between Latin America, the Middle East, and Asia according to the participants' responses. Furthermore, there were no significant differences in rankings of groups between men and women. Based on the Levitt and List model, we expect participants in the dictator game to donate most to those perceived most vulnerable and poor; i.e., where the money has the highest perceived impact.

\subsection{Do men and women have different attitudes toward the level of development aid?}

Because the participants in this experiment were students, we find little variation in age and income. There is, however, some indication in the literature that men and women have different preferences for development aid (Eckel \& Grossman, 2008). We asked the participants whether they thought the level of Norwegian development aid should increase or be reduced. The options ranged from "increase considerably" (value 1) to "be reduced considerably" (value 5). Table 4 shows that on average the participants were slightly positive towards increasing Norwegian development aid, but women were significantly more positive than men. Based on the Levitt and List model, we expect the participants most positive to development aid to donate most in the dictator game; i.e., the level of donations should reflect attitudes and norms.

\section{Results from the conjoint analysis dictator game}


We discuss the results as follows: First, we look at the various project attributes and how they affect willingness to donate to development projects. Next, we split the sample into female and male donors and study the effect of gender differences on willingness to donate money to the different project attributes.

\subsection{The willingness to give to different project attributes}

Table 5 presents the results from the panel Tobit regression estimations of the willingness to give to different project attributes (equation 1). The first column shows the results for the whole sample, the second column the results for the female participants, the third column those for the male participants, and the fourth column presents the difference in parameter values between the two subsamples.

First, we consider the results for the whole sample. The average donation was NOK 125. Comparing the three attributes, we found that the recipient group had the highest impact on willingness to give. The participants were willing to give an average of NOK 55 more to projects directed at children compared with projects for men. The other two attributes had a smaller spread between the different options. Health projects was the most popular of the project types, receiving an average of NOK 22 more than peace and reconciliation projects, which were allocated the smallest average donation. For the third attribute, the recipient region, the difference between the recipient of the largest donations, Sub-Saharan Africa, and that of the smallest, Eastern Europe, was an average of NOK 26.

Regarding recipient groups, we find that all groups receive significantly larger sums than the comparison group (men), and children get the most, followed by girls, women, and boys. This experimental result shows the same order of the recipient groups as we found in the 
vulnerability of recipient groups (Table 3). Projects for children receive significantly more money than those for girls (Wald $\mathrm{W}=7.90 ; p<0.01$ ), boys ( $\mathrm{W}=28.51 ; p<0.01$ ), or women (W $=17.71 ; p<0.01)$. It is also the case that projects to help girls receive significantly larger sums than similar projects for boys ( $\mathrm{W}=7.03 ; p<0.01$ ), while there is no significant difference between projects aimed toward women compared with projects focusing on boys or girls. However, the results indicate some gender sensitivity when donating money. Here it is worth noting that we did not specify the age of the recipients, and the larger donations to children than to girls and boys can have two reasons. First, children may be perceived as younger than girls and boys. A second explanation may be that people dislike charity projects differentiating with respect to gender when it comes to children.

Considering recipient regions, our results indicate a significantly greater willingness to give to all other regions compared with Eastern Europe. Sub-Saharan Africa receives NOK 26 more than Eastern Europe, the Middle East NOK 22 more, Asia NOK 18 more, and Latin America NOK 14 more. The difference between the parameter values of Sub-Saharan Africa and Latin America is significant ( $\mathrm{W}=5.26 ; p=0.02)$, while those of the others are not. All significant differences correspond to the results of perceived poverty in the regions (Table 3), with Sub-Saharan Africa at the top and Eastern Europe at the bottom.

Looking at the project types, we find that health (NOK 22) and education (NOK 20) projects receive relatively more support than agriculture (NOK 16), and all three types receive significantly more than peace projects (the comparison project type). There is no significant difference between willingness to give to peace projects and to business development projects. Furthermore, the difference is significant between willingness to give to business development 
projects and to both health ( $\mathrm{W}=5.66 ; p=0.02)$, and education projects ( $\mathrm{W}=4.13 ; p=0.04)$, but not between the other.

From these results we can conclude that the project triggering the highest average donation would be a health project aimed at children in Sub-Saharan Africa. The results in Table 5 indicate that this project would receive an average of NOK 184 in our dictator game (health project (NOK 22) plus children (NOK 55) plus Africa (NOK 26) plus the constant (NOK 81)). The project receiving the least would be a peace project aimed toward men in Eastern Europe. According to our model, such a project would receive only NOK 81 (the constant) on average in the dictator game. As discussed in section 2.5, these results do not translate directly to the field, but are clear indications of the type of development aid projects to which people prefer to donate money.

\subsection{Do men and women have different preferences when it comes to donations?}

Previous research has found that men and women have different preferences for development aid, and we also found a significant difference between female and male donors in our questionnaire (see Table 4). We therefore investigate this difference further using the dictator game. From the overall statistics of the donations, we find that female donors donated an average of NOK 133 while male donors gave NOK 105, a highly significant difference. We explore this difference by estimating male and female specific Tobit parameters. These parameters are presented in the second and third columns in Table 5.

The results indicate that female donors pay more attention to, and distinguish more between, the recipient groups than male donors. They give almost NOK 62 more to children than to men, and differentiate by both gender and age, but place more importance on gender than on 
age. The order for female donors shows that children receive the most, then girls, women, boys, and men. They give almost NOK 19 more to girls than to boys, a significant difference ( $\mathrm{W}=$ 8.11; $p<0.01)$. Furthermore, the difference between amounts of donations for women and boys is also significant $(\mathrm{W}=3.69 ; p=0.05)$, but not women and girls. Finally, children receive significantly more from female donors than all other groups (children vs. girls, $\mathrm{W}=7.44 ; p<$ 0.01; children vs. women, $\mathrm{W}=12.36 ; p<0.01$; children vs. boys, $\mathrm{W}=28.64 ; p<0.01$ ).

Male donors, on the other hand, seem to differentiate more by age than by gender. They give NOK 42 more to children than to men, but there is no significant difference between amounts donated for children, boys, and girls, or between those donated for men and women. The only significant difference is between amounts donated for children and for women ( $\mathrm{W}=$ 7.45; $p<0.01$ ). Thus, they discriminate much less between recipient gender than do female donors.

Regarding project type, female donors seem to value health and educational projects significantly higher than peace and reconciliation projects and business development projects (health vs. business development, $\mathrm{W}=4.02 ; \mathrm{p}=0.05$; education vs. business development, $\mathrm{W}=$ 4.32; $\mathrm{p}=0.04)$. Payments to agricultural projects and business development projects were not significantly different from those to peace and reconciliation projects. Male donors have a different pattern. They show no significant difference between the four project types other than peace and reconciliation projects, but all four receive significantly more money than the peace and reconciliation projects. Thus, it seems that a major difference between men and women is that female donors value peace and reconciliation projects higher than do male donors. Female donors also have a special liking for health and educational projects. 
Both male and female donors give significantly less to projects in Eastern Europe than to those in the other regions. Female donors give the most to projects in Sub-Saharan Africa, followed by the Middle East, Asia, Latin America, and finally Eastern Europe. Sub-Saharan Africa receives significantly more than Latin America $(\mathrm{W}=6.14 ; p=0.01)$ and Asia $(\mathrm{W}=3.16$; $p<0.08$ ), but none of the other differences are significant. For male donors there are no significant differences between the four regions other than Eastern Europe. This might indicate that male donors are indifferent between the first four regions and more uniformly negative toward Eastern Europe than female donors.

Finally, we find that the constant in the male donor equation is only NOK 45, while it is NOK 96 for female donors, indicating that female donors value the combination of Eastern Europe, peace and reconciliation, and male recipients higher than do male donors. Also, for the most preferred projects, the difference between the female and male donors is approximately NOK 50. The model predicts that women would give NOK 201 to a health project for children in Africa, while men would give NOK 148 toward a similar project in Asia.

We also tested whether there are statistically significant differences between the regressors for male and female donors. The results are presented in the last column of Table 5. With our relatively small sample, 63 women and 27 men, only three coefficients are found to be significantly different. Female donors on average give more than male donors, differentiating between projects for men and women to a greater extent, and less than men with respect to the peace or health projects.

\section{Conclusions}


Combining well-tested methods from marketing and experimental economics, we designed an incentive-aligned method with real donations to elicit donors' preferences for attributes of charity projects. We designed a conjoint analysis experiment with three five-level project attributes, and asked each participant to rate 15 of the project profiles by donating money in a dictator game. One of the profiles was randomly drawn as binding, and the money the participants had stated they would donate to the binding project was sent to a charity with such a project.

We study charity donors preferences for recipient group (children, girls, boys, women, and men), recipient region (Sub-Saharan Africa, South and Southeast Asia, Middle East, Latin America, and Eastern Europe), and project type (education, health, peace and reconciliation, agriculture, and business development). The method can easily be transferred to other types of projects to which people donate money, such as culture or environment projects.

We find that the participants on average donate most to projects benefitting groups and regions that they perceive as the most vulnerable and poor. Children are seen as most vulnerable and receive the largest donations, while men are seen as the least vulnerable and receive the smallest donations. Sub-Saharan Africa is seen as the poorest region and receives the largest donations, while Eastern Europe is seen as the least poor and receives the smallest donations. When it comes to recipient groups, female donors place more weight on gender than age, in contrast to male donors, and thus give more to women than to boys. It also seems that male donors focus on income-generating activities to a greater extent than female donors, and female donors are more inclined to believe in peace and reconciliation projects than male donors.

Our results, indicating that people want to donate more to the most vulnerable and poor, are consistent with evidence from the field. Norwegian development aid charities focusing on 
children obtain the largest proportion of private donations. At the top of the list, with $90 \%$ of their contributions from private donations, we find SOS Children's Villages, an NGO focusing on orphans and children without parental care. If we consider donations from private sources in Norway, we find three charity organizations focusing on children at the top: SOS Children's Villages, Save the Children, and Plan (Bolle, 2010). Organizations that do not focus on children have a harder time attracting private donors.

We discovered two important differences with respect to triggering donations from men and women. Men have a larger spread between the most and least preferred project type than women, indicating that thematic information may be more important for men than women in triggering donations. Women favor girls and women over boys and men, while men only discriminate between gender of adults. Here it is worth noting that we did not specify the age of the boys. The fact that there are clear segments among the donors means that efficient marketing campaigns should utilize these differences in attracting donations from various groups.

For governments donating money to charity organizations, it is important to realize that for many good causes, it can be very difficult to raise money from private donors. Hence, if a government wants to increase the amount of money going to projects focusing on to such things as peace and reconciliation, agriculture, and business development they cannot rely on private donors. They would need to provide more funds for such projects than to projects aimed at children. 


\section{References}

Akerlof, G.A., Kranton, R.E., 2000. Economics and identity. Quarterly Journal of Economics 115, 715-753.

Andreoni, J., 1990. Impure altruism and donations to public goods: A theory of warm-glow giving. The Economic Journal 100, 464-477.

Andreoni, J., 2006. Philanthropy. In S-C. Kolm, J. Mercier Ythier, Eds., Handbook of Giving, Reciprocity and Altruism pp. 1201-1269. Amsterdam: North Holland.

Andreoni, J., 2007. Charitable giving. In S. N. Durlauf, L. E. Blume Eds., The New Palgrave Dictionary Of Economics 2nd ed. New York: Palgrave Macmillan.

Andreoni, J., Harbaugh, W.T., Vesterlund, L., 2007. Altruism in experiments. In S. Durlaf, L. Blume Eds., The New Palgrave Dictionary of Economics, 2nd ed.. Houndmills, UK: Palgrave McMillan.

Andreoni, J., Miller, J., 2002. Giving according to GARP: An experimental test of the consistency of preferences for altruism. Econometrica 70, 2737-2753.

Andreoni, J., Payne, A., 2008. Crowding out both sides of the philanthropy market: evidence from a panel of charities. Working Paper.

Andreoni, J., Vesterlund, L., 2001. Which is the fair sex? Gender differences in dltruism. Quarterly Journal of Economics 116, 293-312.

Atkinson, A.B., Backus, P.G., Micklewright, J., Pharoah, C., Schnepf, S.V ., 2008. Charitable Giving for Overseas Development: UK Trends over a Quarter Century. IZQA DP. No. 3872.

Bardsley, N., R. Cubitt, G. Loomes, P. Moffatt, C. Starmer, and R. Sugden. 2010. Experimental Economics: Rethinking the Rules. Princeton and Oxford: Princeton 
University Press. Bohnet, I. and B. S. Frey (1999). "Social distance and other-regarding behavior in dictator games: Comment." American Economic Review 89(1): 335-339.

Bohnet, I. and B. S. Frey (1999). "The sound of silence in prisoner's dilemma and dictator games." Journal of Economic Behavior \& Organization 38(1): 43-57.

Brekke, K.A., Hauge, K.E., Lind, J.T., Nyborg, K., 2009. Playing with the good guys. A public good game with endogenouse group formation. CESifo Working Paper No. 2647.

Benz, M., Meier, S., 2008. Do people behave in experiments as in the field? Evidence from donations. Experimental Economics 11, 268-281.

Bolle, T.A ., 2010. Norsk bistand er blitt milliardbutikk. Accessed June 25, 2010. www.bistandsaktuelt.no.

Bolton, G.E., Katok, E ., 1995. An experimental test for gender differences in beneficent behavior. Economics Letters 48, 287-292.

Breman, A., Granström, O., 2008 The more we know, the more we care? Identification and deservingness in a cross-border experiment. Unpublished paper. Accessed June 25, 2010. http://www.u.arizona.edu/ breman/.

Burt, C.D.B., Popple, J.S ., 1998. Memorial distortions in donation data. Journal of Social Psychology 138, 724-733.

Cappelen, A.W., Hole, A.D., Sørensen, E.Ø., Tungodden, B., 2007. The pluralism of fairness ideals: an experimental approach. American Economic Review 97, 818-827.

Carlsson, F. Martinsson, P., 2001. Do hypothetical and actual marginal willingness to pay differ in choice experiments? Application to the valuation of the environment. Journal of Environmental Economics and Management 41, 179-192. 
Carpenter, J., Connolly, C., Myers, C., 2008. Altruistic behavior in a representative dictator experiment. Experimental Economics, 11, 282-298.

Chang, J.B., Lusk, J.L., Norwood, F.B., 2009. How closely do hypothetical surveys and laboratory experiments predict field behavior? American Journal of Agricultural Economics 91, 518-534.

Charness, G., Gneezy, U., 2008. What's in a name? Anonymity and social distance in dictator and ultimatum games. Journal of Economic Behavior Organization 68, 29-35.

Cherry, T.L. Frykblom, P. Shogren, J.F. 2002. Hardnose the dictator. American Economic Review 92, 1218-1221.

DellaVigna, S. List, J. A., Malmendier, U, 2012. Testing for Altruism and Social Pressure in Charitable Giving. Quarterly Journal of Economics 127, 1-56.

Ding, M., Grewal, R., Liechty, J., 2005. Incentive-aligned conjoint analysis. Journal of Marketing Research 42, 67-82.

Dong, A., Ding, M., Huber, J., 2010. A simple mechanism to incentive-align conjoint experiments. International Journal of Research in Marketing 27, 25-32.

Dufwenberg, M., Muren, A., 2006. Generosity, anonymity, gender. Journal of Economic Behavior \& Organization 61, 42-49

Eckel, C. C., Grossman, P.J., 1996 Altruism in anonymous dictator games. Games and Economic Behaviour 16, 181-91.

Eckel, C.C., Grossman, P.J., 1998. Are women less selfish than men? Evidence from dictator experiments. The Economic Journal 108, 726-735. 
Eckel, C.C., Grossman. P.J., 2008. Differences in the economic decisions of men and women: Experimental evidence. In Plott, C.R. Smith, V.L. eds Handbook of Experimental Economics. Elsevier. 509-519.

Engel, C. 2011. Dictator Games: a meta study. Experimental Economics 14: 583-610.

Falk, A., Heckman, J.J. 2009. Lab experiments are a major source of knowledge in social sciences. Science 326, 535-538.

Fong, C.M., Luttmer, E.F.P., 2009. What determines giving to Hurricane Katrina victims? Experimental evidence on racial group loyalty. American Economic Journal: Applied Economics, 1:2, 64-87.

Green, P.E., Krieger, A.M., Wind, Y., 2001. Thirty years of conjoint analysis: reflections and prospects. Interfaces 31(3), s56-s73.

Green, P. E., Srinivasan. V., 1990. Conjoint analysis in marketing: new developments with implications for research and practice. Journal of Marketing 54(4) , 3-19.

Hoffman, E., McCabe, K., Smith, V., 1996. Social distance and other-regarding behavior in dictator games. American Economic Review 86, 653-660.

Johansson-Stenman, O., Svedsäter, H., 2008. Measuring hypothetical bias in choice experiments: The importance of cognitive consistency. The B.E. Journal of Economic Analysis Policy 8, Issue 1, Article 41.

Kuhfeld, W.F., 2009. Marketing Research Methods in SAS: Experimental Design, Choice, Conjoint, and Graphical Techniques, SAS 9.2 Edition, MR-2009.

Landry, C., Lange, A., List. J.A., Price, M. K., Rupp, N.G ., 2006. Toward an understanding of the economics of charity: evidence from a field experiment. Quarterly Journal of Economics 121, 747-782. 
Laury, S.K., Taylor, L.O., 2008. Altruism spillovers: Are behaviors in context-free experiments predictive of altruism toward a naturally occurring public good? Journal of economic behavior and organization 65, 9-29.

Lee, Z., Woodliffe, L., 2010. Donor misreporting: Conceptualizing social desirability bias in giving surveys. Voluntas 21, 569-587

Levitt, S. D., List. J.A., 2007 What do laboratory experiments measuring social preferences reveal about the real world? Journal of Economic Perspectives 21, 153-174.

List, J.A., 2007. On the interpretation of giving in dictator games. Journal of Political Economy 115, 482-493.

List, J.A., Lucking-Reiley, D., 2002. The effects of seed money and refunds on charitable giving: experimental evidence from a university capital campaign. Journal of Political Economy $110,215-233$.

Micklewright, J., Schnepf, S.V., 2007. Who gives for overseas development? IZA Discussion Paper No. 3057.

Norwood, F. B. and J. L. Lusk (2011). Social desirability bias in real, hypothetical, and inferred valuation experiments." American Journal of Agricultural Economics, 93, 528-534.

OECD 2012. OECD.Stat Extracts. Accessed April 24, 2012. http://stats.oecd.org/Index.aspx?DatasetCode=ODA_DONOR

Otter, T., Tüchler, R., Frühwirth-Schnatter, S., 2004. Capturing consumer heterogeneity in metric conjoint analysis using Bayesian mixture models. International Journal of Research in Marketing 21, 285-297.

Rao, V.R ., 2008. Developments in conjoint analysis, in B. Wierenga, ed., Handbook of Marketing Decision Models. Springer US. pp., 23-53. 
Rege, M., Telle, K., 2004. The impact of social approval and framing on cooperation in public good situations. Journal of Public Economics 88, 1625-1644.

Schelling, T. (1968). The life you save may be your own, Problems in public expenditure analysis, edited by S. Chase. Washington DC: Brookings Institution, pp. 127-62.

Supphellen, M., Nelson, M. R., 2001. Developing, exploring, and validating a typology of private philanthropic decision making. Journal of Economic Psychology 22, 573-603.

Vermeulen, B., Goos, P., Vandebroek, M., 2008. Models and optimal designs for conjoint choice experiments including a no-choice option. International Journal of Research in Marketing 25, 94-103.

Wittink, D.R., Vriens, M., Burhenne, W., 1994. Commercial use of conjoint analysis in Europe. International Journal of Research in Marketing 11, 41-52.

Wollebæk, D, Sivesind, K.H., 2010. Fra folkebevegelse til filantropi? Frivillig innsats i Norge 1997-2009. Senter for forskning på sivilsamfunn og frivillig sektor. Rapport 2010:3. 


\section{Table 1}

Descriptive statistics of the student sample.

\begin{tabular}{llcc}
\hline Variable & Definition & Mean & Standard deviation \\
\hline Gender & Gender of participant & & \\
& Male = 0, Female = & 0.7 & 0.46 \\
Age & Age of participant & 22.83 & 3.77 \\
Years at university & $\begin{array}{l}\text { Years as a student at } \\
\text { university level }\end{array}$ & 2.86 & 1.63 \\
\hline $\mathrm{n}=90$ & & &
\end{tabular}


Table 2

Examples of the project descriptions used in the dictator game. Each participant got 15 out of 60 project profiles

\begin{tabular}{|c|c|c|}
\hline Project & Project description & $\begin{array}{l}\text { How much do you } \\
\text { want to give? }\end{array}$ \\
\hline 1 & $\begin{array}{l}\text { Peace and reconciliation project aimed at } \underline{\text { men }} \text { in } \\
\text { a country in Latin America }\end{array}$ & NOK: \\
\hline 2 & $\begin{array}{l}\text { Health project aimed at girls in a country in } \\
\text { Africa south of the Sahara }\end{array}$ & NOK: \\
\hline 3 & $\begin{array}{l}\text { Educational project aimed at children in an } \\
\text { Eastern European country }\end{array}$ & NOK: \\
\hline
\end{tabular}




\section{Table 3}

Participants' views of vulnerabilities of different recipient groups and poverty in recipient areas.

\begin{tabular}{lcccccc} 
& \multicolumn{2}{c}{ All participants } & \multicolumn{2}{c}{ Women } & \multicolumn{2}{c}{ Men } \\
\hline Recipient group $^{\mathbf{1}}$ & Mean & St. dev. & Mean & St. dev. & Mean & St. dev. \\
\hline Girls & 1.89 & 1.02 & 1.89 & 1.04 & 1.89 & 1.01 \\
Women & 2.30 & 1.04 & 2.25 & 1.06 & 2.41 & 1.01 \\
Boys & 3.52 & 1.06 & 3.53 & 1.05 & 3.48 & 1.12 \\
Men & 4.65 & 1.08 & 4.69 & 1.06 & 4.55 & 1.12
\end{tabular}

\begin{tabular}{lcccccc} 
Recipient region $^{2)}$ & Mean & St. dev. & Mean & St. dev. & Mean & St. dev. \\
\hline Sub-Saharan Africa & 1.66 & 0.98 & 1.71 & 1.02 & 1.52 & 0.89 \\
Middle East & 2.81 & 1.26 & 2.79 & 1.03 & 2.85 & 1.26 \\
Asia & 2.98 & 1.02 & 2.92 & 1.0 & 3.11 & 1.05 \\
Latin America & 2.99 & 0.98 & 3.0 & 0.95 & 2.96 & 1.04 \\
Eastern Europe & 3.62 & 1.09 & 3.48 & 1.08 & 3.96 & 1.06 \\
\hline
\end{tabular}

$\mathrm{n}=90$

1) Question: How vulnerable do you think each of the following recipient groups is? Measures were from 1 to 7, where 1 was extremely vulnerable and 7 was not vulnerable.

2) Question: How much misery and poverty do you think there is in each of the following regions? Measures were from 1 to 7 , where 1 was very much and 7 was very little. 


\section{Table 4}

Attitudes towards Norwegian development aid: should it increase or decrease?

\begin{tabular}{lcccc}
\hline Participants & $\mathrm{n}$ & Mean value & Median value & St. dev. \\
\hline Women & 63 & 2.51 & 2 & 0.88 \\
Men & 27 & 3.02 & 3 & 1.07 \\
All respondents & 90 & 2.70 & 3 & 0.99 \\
\hline
\end{tabular}

Note: Question: Do you think Norwegian development aid should increase, remain the same, or be reduced? Measures were from 1 to 5 . One means increase development aid considerably, while 5 means reduce it considerably. 
Table 5

Willingness to give to different recipient groups, regions, and project types: Tobit estimation of the conjoint analysis dictator game.

\begin{tabular}{|c|c|c|c|c|}
\hline & $\begin{array}{l}\text { Overall } \\
\text { sample } \\
(1)\end{array}$ & $\begin{array}{c}\text { Women } \\
(2)\end{array}$ & $\begin{array}{l}\text { Men } \\
\text { (3) } \\
\end{array}$ & $\begin{array}{l}\text { Parameter diff. } \\
\text { gender seg. } \\
(4)\end{array}$ \\
\hline \multicolumn{5}{|l|}{ Recipient group } \\
\hline Children & $\begin{array}{l}55.03 * * * \\
(9.54)\end{array}$ & $\begin{array}{l}61.74^{* * *} \\
(8.56)\end{array}$ & $\begin{array}{l}42.34^{* * *} \\
(4.61)\end{array}$ & $\begin{array}{l}18.20 \\
(1.47)\end{array}$ \\
\hline Girls & $\begin{array}{l}39.16^{* * * *} \\
(7.22)\end{array}$ & $\begin{array}{l}42.46^{* * *} \\
(6.41)\end{array}$ & $\begin{array}{l}30.58^{* * *} \\
(3.36)\end{array}$ & $\begin{array}{l}10.75 \\
(0.90)\end{array}$ \\
\hline Boys & $\begin{array}{l}25.06^{* * * *} \\
(4.59)\end{array}$ & $\begin{array}{l}23.86^{* * * *} \\
(3.54)\end{array}$ & $\begin{array}{l}28.96^{* * * *} \\
(3.24)\end{array}$ & $\begin{array}{l}-5.75 \\
(-0.48)\end{array}$ \\
\hline Women & $\begin{array}{l}30.87^{* * *} \\
(7.07)\end{array}$ & $\begin{array}{l}36.58^{* * * *} \\
(6.84)\end{array}$ & $\begin{array}{l}17.13^{* *} \\
(2.36)\end{array}$ & $\begin{array}{l}19.09 * * \\
(1.99)\end{array}$ \\
\hline \multicolumn{5}{|l|}{ Recipient region } \\
\hline Sub-Saharan Africa & $\begin{array}{l}26.01^{* * *} \\
(5.40)\end{array}$ & $\begin{array}{l}26.15^{* * *} \\
(4.39)\end{array}$ & $\begin{array}{l}25.30 * * * \\
(3.20)\end{array}$ & $\begin{array}{c}0.19 \\
(0.02)\end{array}$ \\
\hline Middle East & $\begin{array}{l}21.81^{* * * *} \\
(4.44)\end{array}$ & $\begin{array}{l}20.57^{* * * *} \\
(3.39)\end{array}$ & $\begin{array}{l}24.50^{* * * *} \\
(3.04)\end{array}$ & $\begin{array}{l}-4.26 \\
(-0.40)\end{array}$ \\
\hline South and Southeast Asia & $\begin{array}{l}18.93^{* * * *} \\
(3.88)\end{array}$ & $\begin{array}{l}15.55^{* * * *} \\
(2.59)\end{array}$ & $\begin{array}{l}28.30^{* * * *} \\
(3.50)\end{array}$ & $\begin{array}{c}-13.37 \\
(-1.25)\end{array}$ \\
\hline Latin America & $\begin{array}{l}14.30 \text { *** } \\
(2.76)\end{array}$ & $\begin{array}{l}10.59 * \\
(1.67)\end{array}$ & $\begin{array}{l}23.41^{* * *} \\
(2.72)\end{array}$ & $\begin{array}{c}-13.50 \\
(-1.18)\end{array}$ \\
\hline \multicolumn{5}{|l|}{ Project type } \\
\hline Health & $\begin{array}{l}21.59 * * * \\
(4.91)\end{array}$ & $\begin{array}{l}16.65^{* * *} \\
(3.06)\end{array}$ & $\begin{array}{l}32.16^{* * *} \\
(4.49)\end{array}$ & $\begin{array}{c}-16.20^{*} \\
(-1.69)\end{array}$ \\
\hline Education & $\begin{array}{l}19.80^{* * * *} \\
(4.39)\end{array}$ & $\begin{array}{l}17.39 * * * \\
(3.13)\end{array}$ & $\begin{array}{l}23.42^{* * *} \\
(3.15)\end{array}$ & $\begin{array}{l}-6.63 \\
(-0.67)\end{array}$ \\
\hline Agriculture & $\begin{array}{l}15.86^{* * * *} \\
(2.68)\end{array}$ & $\begin{array}{l}11.19 \\
(1.54)\end{array}$ & $\begin{array}{l}26.59^{* * * *} \\
(2.71)\end{array}$ & $\begin{array}{c}-16.21 \\
(-1.25)\end{array}$ \\
\hline Business development & $\begin{array}{l}7.709 \\
(1.31)\end{array}$ & $\begin{array}{r}2.215 \\
(0.31)\end{array}$ & $\begin{array}{l}19.58^{* *} \\
(2.02)\end{array}$ & $\begin{array}{c}-17.90 \\
(-1.39)\end{array}$ \\
\hline Female dummy & & & & $\begin{array}{c}52.38^{*} \\
(1.72)\end{array}$ \\
\hline Constant & $\begin{array}{l}80.68^{* * * *} \\
(5.73)\end{array}$ & $\begin{array}{l}96.19 * * * \\
(5.84)\end{array}$ & $\begin{array}{c}45.01^{*} \\
(1.75)\end{array}$ & \\
\hline Sigma_u & $\begin{array}{l}121.2^{* * *} \\
(11.38)\end{array}$ & $\begin{array}{c}117.6^{* * * *} \\
(9.51)\end{array}$ & $\begin{array}{c}123.2 * * * \\
(6.26)\end{array}$ & \\
\hline Sigma_e & $\begin{array}{l}51.00 * * * \\
(40.76)\end{array}$ & $\begin{array}{l}52.79 * * * \\
(34.18)\end{array}$ & $\begin{array}{l}45.24 * * * \\
(22.23)\end{array}$ & \\
\hline $\mathrm{N}$ & 90 & 63 & 27 & \\
\hline
\end{tabular}

NOTE: $t$ statistics in parentheses. ${ }^{*} \mathrm{p}<.1,{ }^{* *} \mathrm{p}<.05$, *** $\mathrm{p}<.01$. For each attribute, region, recipient, and theme, the following is the respective comparison group: Eastern Europe, men, and peace. (4) is the difference between the parameter in the female and male sample. 